\title{
18. Mobile water payments in urban Africa: Adoption, implications and opportunities
}

\author{
Tim Foster \\ Oxford University, United Kingdom \\ Rob Hope \\ Oxford University, United Kingdom \\ Aaron Krolikowski \\ Oxford University, United Kingdom \\ Ilana Cohen \\ Oxford University, United Kingdom
}

The revolution in Africa's mobile communications sector offers new opportunities to address the continent's enduring water service challenges. Over the past decade, mobile phone subscriptions in Africa have grown to over 620 million and, by 2013, more Africans will have a mobile phone subscription than access to an improved water source.

Juxtaposing the rapid upsurge in mobile phone ownership is the slow progress being made towards the water access Millenium Development Goal (MDG). Between 1990 and 2008, the number of urban Africans lacking access to safe water more than doubled from 25 million to 52 million (World Health Organization (WHO)/United Nations Children's Fund (UNICEF) 2010). Many water service providers (WSPs) are unable to meet the needs of a rapidly growing population as they remain trapped in a vicious cycle of poor operational performance and low cost recovery.

A key contributor to this spiral of decline is under-collection of water bills, which costs the urban water sector in Africa almost US\$500 million a year equivalent to 0.07 per cent of the continent's GDP. Around one in five urban households with a piped connection fails to pay for water, while recent World Bank analysis suggests more than half of African utilities collect revenue from fewer than 50 per cent of their customers (Bannerjee and Morella 2011). 


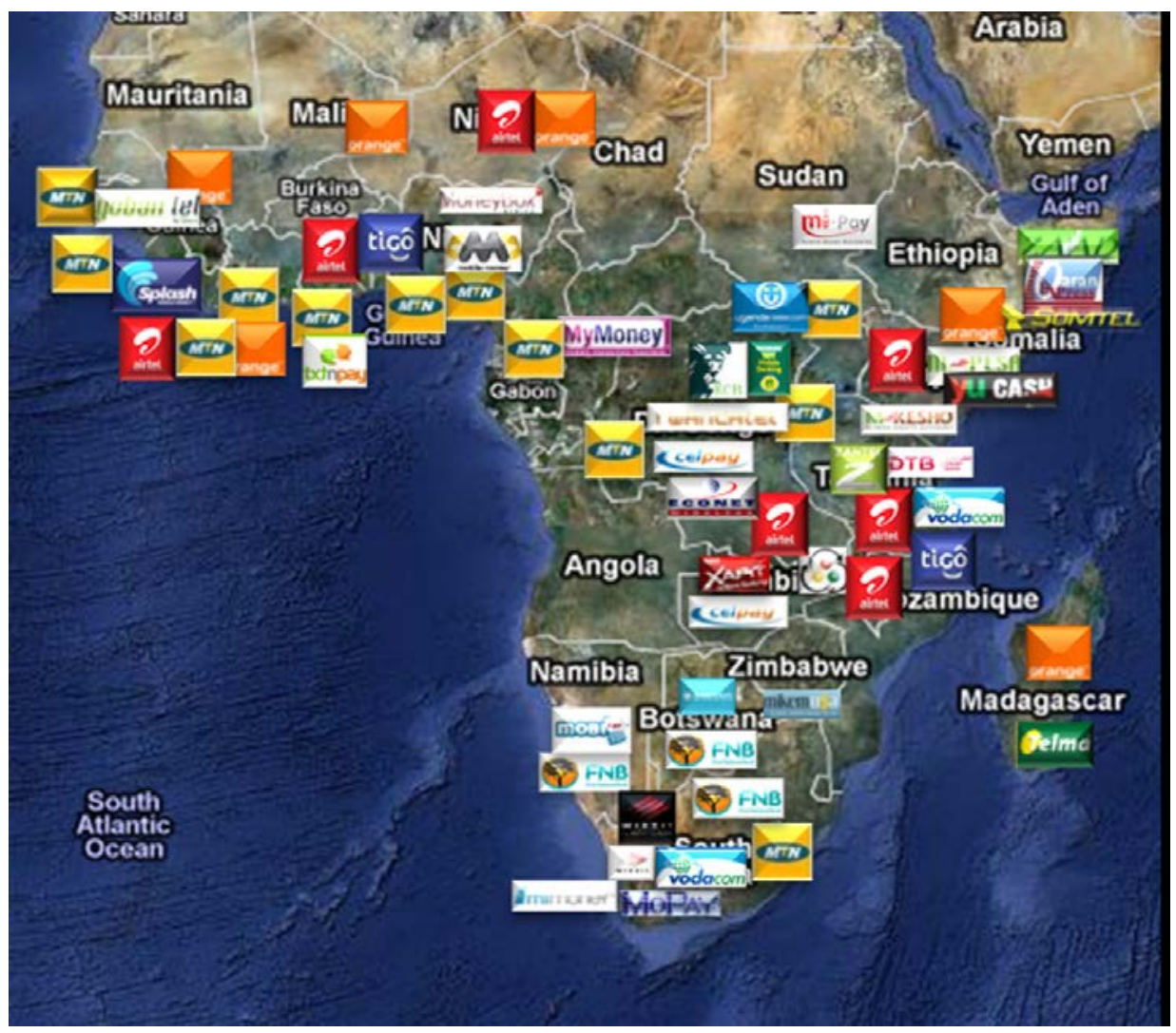
Figure 1: Opportunities for expansion of mobile water payments: mobile
money deployments in Africa to 2011

Source: Authors' research.

In an effort to turn around their ailing financial positions, many WSPs are teaming up with mobile network operators (MNOs) to enable customers to pay their water bills using 'mobile money'. ${ }^{1}$ Since 2009, at least 35 WSPs in east and southern Africa have launched a mobile bill payment service in concert with global MNOs including Safaricom/Vodacom, Airtel and MTN. In order

1 Mobile money is an electronic payment system that enables money transfers to and from an electronic account that can be accessed via an ordinary mobile phone. Each customer's account is linked to their mobile phone number by means of an in-built SIM-card application. Physical cash withdrawals and deposits are facilitated by a network of retail agents. While configurations vary across providers, the viability of mobile money is premised upon the cost base associated with an agent network, which is lower and more flexible than establishing 'bricks and mortar' bank branches. Mobile money can therefore profitably extend the reach of financial services to those who have traditionally been unbanked, such as low-income or remote households. The scale and growth of the opportunities for mobile water payments is demonstrated by Figure 1, which displays mobile money deployments in Africa to 2011. 
to ascertain the implications of this trend, our team conducted a four-country study that examined mobile water payment deployments across Kenya, Tanzania, Uganda and Zambia (Hope et al. 2011).

For the WSPs that we investigated, mobile payment adoption rates range between one and ten per cent of customers (Table 2). In terms of transaction volumes, the National Water and Sewerage Corporation (NWSC) in Uganda leads the way with 23,000 customers transferring US\$300,000 worth of revenue via mobile phone each month. The notable exception to the otherwise low levels of uptake is Kiamumbi, a small peri-urban community on the outskirts of Nairobi, where three quarters of the customer base have switched to the mobile payment option.

Table 1: Mobile water payment adoption rates for studied WSPs

\begin{tabular}{|l|l|l|l|l|l|}
\hline \multirow{2}{*}{ Country } & WSP & $\begin{array}{l}\text { Mobile } \\
\text { network } \\
\text { operator }\end{array}$ & $\begin{array}{l}\text { Served } \\
\text { population }\end{array}$ & $\begin{array}{l}\text { Mobile } \\
\text { payment } \\
\text { adoption }\end{array}$ & $\begin{array}{l}\text { Months } \\
\text { since } \\
\text { launch }\end{array}$ \\
\hline \multirow{3}{*}{ Kenya } & Nairobi City WSC & Safaricom & $2,250,607$ & $4 \%$ & 13 \\
\cline { 2 - 6 } & Kisumu WASCO & Safaricom & 181,512 & $8 \%$ & - \\
\cline { 2 - 6 } & Nanyuki WSC & Safaricom & 57,252 & $1 \%$ & 1 \\
\cline { 2 - 6 } & Kiamumbi WT & Safaricom & 2,922 & $76 \%$ & 11 \\
\hline \multirow{2}{*}{ Tanzania } & Dar es Salaam & Airtel & $2,380,000$ & $1 \%$ & 27 \\
\cline { 2 - 4 } & WASCO & Vodacom & & 7 \\
\hline \multirow{2}{*}{ Uganda } & National WSC & MTN & $2,426,502$ & $10 \%$ & 7 \\
\cline { 2 - 6 } & UTL & Uirtel & $1,285,270$ & - & - \\
\hline Zambia & Lusaka WSC & Air & & \\
\hline
\end{tabular}

Source: Hope et al. 2011.

In order to ascertain the benefits, motivations and barriers relating to customer adoption of mobile water bill payments, we conducted a household survey of water users in Kiamumbi. Time savings (98 per cent) and cost savings (63 per cent) emerged as the key reasons why customers opt to pay bills by mobile phone (Figure 2). On average customers switching to mobile payments save 80 minutes a month, with women being the main beneficiaries. Of the numerous sociodemographic, wealth and water-service satisfaction indicators we subjected to logistic regression analysis, full-time work status emerged as a statistically significant predictor of mobile payment usage. This finding points to the importance adopters place on being able to pay bills outside of business hours. ${ }^{2}$

2 The results from the survey however fail to unravel why Kiamumbi adoption rates are so much higher than elsewhere in east Africa. Some possible explanations include: (a) a longer than average trip to the alternative pay point; (b) a wealthier than average community placing a high value on their time; (c) a high degree of trust in the operators due to the scheme's strong operational performance, small size and community-orientation; and, (d) the high water tariffs which reduce the relative size of the mobile payment fee as a percentage of the overall bill. 

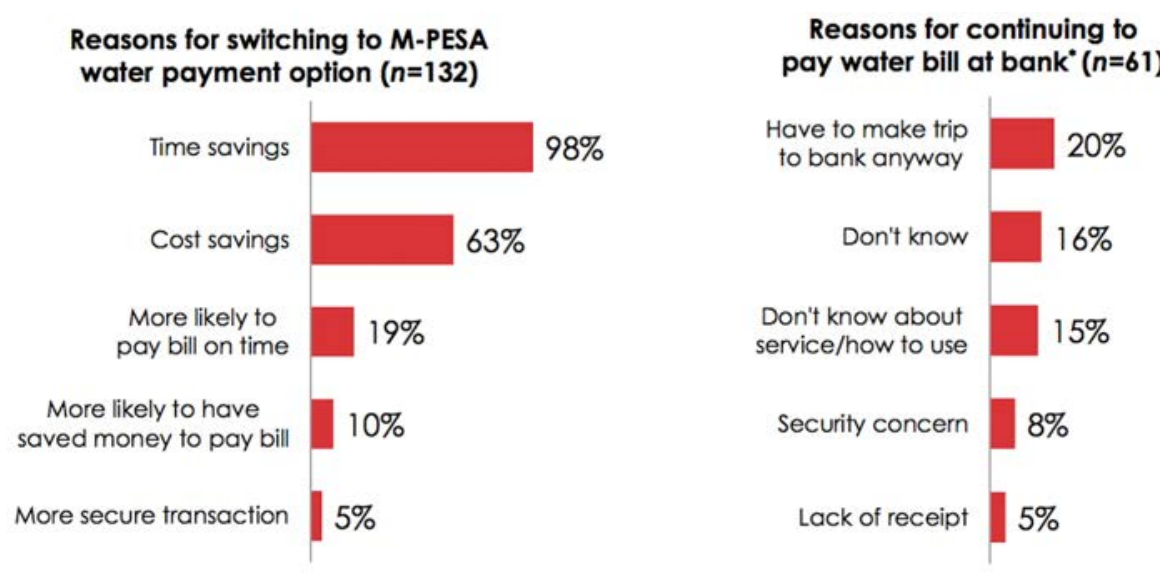

- In addition, $2 \%$ of bank paying customers elected not to switch to M-PESA payments as they considered the transaction tariff too expensive, and $2 \%$ were unable to as they subscribed to an MNO other than Safaricom

Figure 2: Time and cost associated with bank trips are keys drivers behind the adoption of mobile water payments in Kiamumbi

Source: Hope et al. 2011.

Across other large east African WSPs we examined, it is clear there are systemic obstacles hindering large-scale use of the mobile payment option. The first relates to customer perceptions of the integrity and trustworthiness of an electronic billing system. Deployments in Kenya, for example, lack a mechanism for automatically updating the WSPs billing system immediately upon receipt of a mobile payment, fuelling customer fears that last minute payments will not be recognised until after the generation of disconnection lists. Similarly, across all four countries, we noted a general unease associated with conducting a transaction that fails to produce a physical receipt, which has traditionally been an unambiguous proof of payment and defence against disconnection. In a number of the study locations there was a lack of awareness of the mobile payment option, suggesting greater marketing and promotional efforts are needed. Finally, transaction tariffs levied by MNOs on customers (which can be as high as US\$0.30 per payment) are in some cases prohibitive, particularly those tariff structures that penalise low-income households for paying bills in many small instalments.

Where the above-mentioned constraints are released, mobile payments offer considerable benefits for both water users and service providers. For WSPs, operating physical payment offices is costly — utilities need to cover ongoing expenditure relating to rent, labour, insurance and cash transportation. The NWSC estimates its new electronic billing system will save US $\$ 420,000$ per year as a result of pay point closures. Moreover, electronic billing will lower the risk of administrative error and misappropriation, in turn building greater 
consumer trust and willingness to pay. Perhaps most importantly, the increased convenience of bill payment is likely to drive an increase in revenue collection ratios. In Kiamumbi, for example, those using mobile payments are now ten per cent more likely to pay by the bill payment deadline than their counterparts paying at the bank. Results from Kiamumbi also illustrated the time and cost savings that mobile bill payments can generate for customers (Figure 3). Replicating these productivity gains across other urban centres in Africa will lead to significant social and economic benefits.

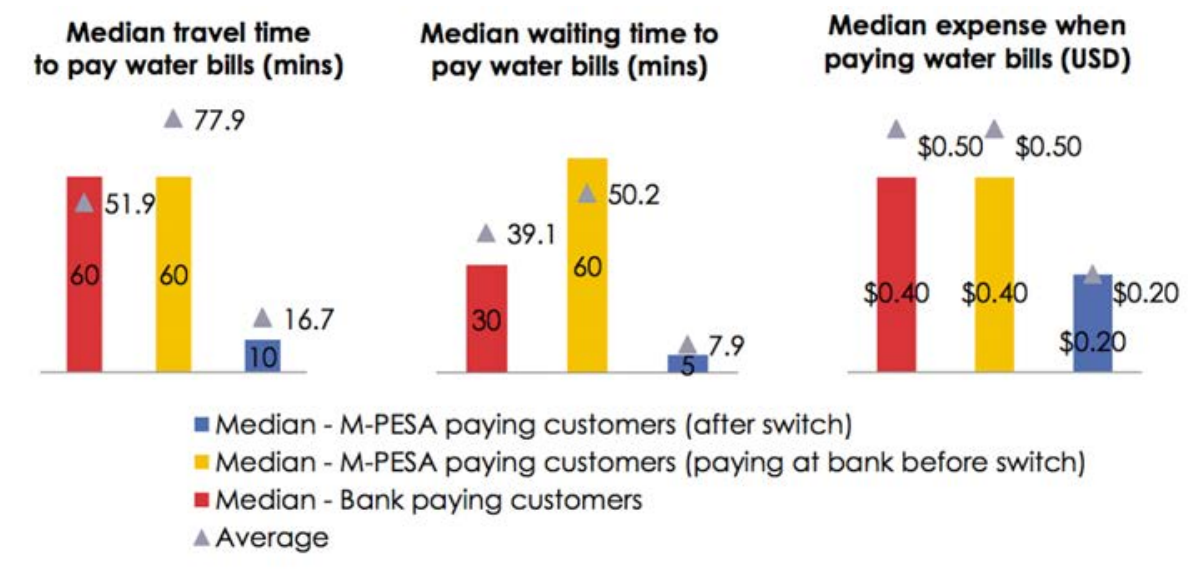

Note: M-PESA users assumed to deposit cash with agent for each monthly bill payment.

\section{Figure 3: Indicative transaction costs for those taking a trip by public transport to pay water bills}

Source: Hope et al. 2011.

With the mutual benefits that mobile water payments afford, this revenue collection mechanism can help provide the circuit-breaker that many African utilities seek to escape the vicious cycle of low cost recovery and poor operational performance. Ultimately, it is hoped this will translate into more reliable water services for customers and network expansions for the unserved. Technical and pricing innovations could also unlock mobile payment solutions that can directly benefit low-income, unconnected water users by eliminating profiteering operators from standpipes and providing a more secure and transparent mechanism in which rural communities can store funds for waterpoint maintenance. Yet, despite the significant potential, mobile water payments are only an instrument for transferring and storing money. Ultimately, the scale of the impact will depend upon the institutional, financial, operational, and regulatory responses that put this tool to good effect. 
Global Water: Issues and Insights

Tim Foster is a PhD student at the Smith School of Enterprise and the Environment, Oxford University.

Dr Rob Hope is Director of the Water Programme at the Smith School of Enterprise and the Environment.

Aaron Krolikowski is a PhD student at the Smith School of Enterprise and the Environment.

Ilana Cohen was formerly a Researcher at Oxford University and is now the Africa Project Manager with Mobile Enabled Community Services at GSMA in Nairobi.

\section{References}

Bannerjee, S. and Morella, E., 2011. 'Africa's water and sanitation infrastructure: access, affordability, and alternatives', The World Bank, Washington D.C. Available at: http://water.worldbank.org/water/node/84013.

Foster, T., Hope, R.A., Thomas, M., Cohen, I., Krolikowski, A. and Nyaga, C., 2012. 'Impacts and implications of mobile water payments in East Africa', Water International. DOI:10.1080/02508060.2012.738409.

Hope, R.A., Foster, T., Krolikowski, A. and Cohen, I., 2011. 'Mobile water payment innovations in urban Africa', School of Geography and Skoll Centre for Social Entrepreneurship at Säid Business School, Oxford University, United Kingdom. Available at: http://oxwater.co.uk/\#/mobile-water-payments/4559323117.

World Health Organization (WHO)/United Nations Children's Fund (UNICEF), 2010. 'Joint Monitoring Programme for Water Supply and Sanitation Data Tables'. Available at: http://www.wssinfo.org/data-estimates/table/. 
This text taken from Global Water: Issues and Insights by R. Quentin Grafton, Paul Wyrwoll, Chris White and David Allendes, published May 2014 by ANU Press, The Australian National University, Canberra, Australia. 